\title{
The Influence of Internal Control System, Information Technology Utilization, and Organizational Commitment on Government Accountability Performance
}

\author{
Dena Handayani \\ Faculty of Economics and Business \\ Universitas Padjadjaran \\ Nunuy Nur Afiah \\ Faculty of Economics and Business \\ Universitas Padjadjaran \\ Ivan Yudianto \\ Faculty of Economics and Business \\ Universitas Padjadjaran
}

\begin{abstract}
Each government institution has a mission to be achieved. Goals and objectives achievement that has been set through the system of accountability performance is a common indicator to measure mission accomplishment. There are several district and municipals in the province of West Java that has poor accountability performance. This study aims to determine the effect of the government internal control system, information technology utilization and organizational commitment on accountability performance of government institutions. The research adopts a quantitative interpretive approach. The population in this study is six districts and municipals in West Java Province, where each district and municipals consists of 5 local government working unit. The data analysis technique in this study uses multiple linear regression. The results of this study indicate that partially and simultaneously, there is a positive and significant influence between the government internal control system, information technology utilization and organizational commitment on accountability performance of government institutions.
\end{abstract}

Keywords: Government internal control system; Information technology utilization; Organizational commitment; Government institution performance accountability

\section{Introduction}

The implementation of regional autonomy is regulated in Law Number 9/2015 concerning Regional Government (Pratiwi and Setyowati, 2017). Regional autonomy is the granting of authority to the regions to make decisions related to the management of their resources in accordance with the interests, priorities and potential of the region. Accountability is believed to be able to change the conditions of government that can provide excellent public services towards democratic governance. Concerning the implementation of regional autonomy, efforts to realize good governance have begun to be rolled out by building a regulatory instrument (Pamungkas, 2012). In the field of government administration, laws and regulations have also been introduced, such as Presidential Regulation Number 29/2014 concerning Government Institution Performance Accountability Systems. Performance accountability is a manifestation of the obligation of a government institution to be able to account for the success or failure of the implementation of the organization's vision and mission in achieving predetermined goals and objectives. The level of performance of the government organization can be identified from the absorption of the budget. The size of the budget leakage can be proven from the findings 
of the Financial Supervisory Agency related to the number of state losses (Tiasari, 2013).

According to Ramdhan (2014), the government performance accountability report is an accountability report to be prepared by the government institution to the public and acting authorities which is an obligation to be prepared by the government institution. Achievement of goals and objectives indicates the level of performance. Santoso (2013) states that the purpose of performance accountability reports is to realize the government institution performance accountability to those who provide the mandate. Performance accountability report is a tool for a government institution to communicate and respond to what has been achieved. Accountability performance of district/municipal governments in West Java during 2016 - 2018 shows the sub-optimal achievement. In 2018, the government institution performance accountability identified six districts/cities that had sufficient value, and two districts/ cities still had less value.

Tiasari (2013) revealed that the accountability of government institution performance could be achieved if human resources have high self-quality. Risk assessment can reduce obstacles that threaten the organization and encourage the realization of performance accountability. Control activities are carried out regularly to minimize fraud and control of all units. Monitoring is carried out periodically to ensure accountability. A sound internal control system is expected to improve the reliability of financial reports (Karmila, et al 2014). The results of an evaluation of the internal control system conducted by the Indonesian Supreme Audit Board revealed cases of weaknesses in internal control which were classified as (1) weaknesses in the accounting and reporting control system (2) weaknesses in the control system for the implementation of the revenue and expenditure budget, and (3) weaknesses in internal control structures.

Chintya (2015) founds that the use of information technology and government internal control systems significantly influence the performance of government institution. A sound internal control system in a government will give confidence to the government that the activities carried out have been carried out in accordance with the benchmarks that have been set effectively and efficiently. Afrina (2015) reveals that government internal control will be able to minimize deviations and waste and maximize the efficient and effective performance of government institution.

The information technology utilization by the government and local governments is regulated in Indonesia Government Regulation number 56/2005 concerning regional Financial Information Systems. The development of science and information technology makes it easy for management in a government institution to create, run and oversee policies that have been determined (Zodia, 2015). With the application of technology, the organization will experience a change of management system, from a traditional system to a contemporary management system so that it will improve the quality and speed of service (Mardjiono 2009). Sutarman (2012:19) states that the benefits of applying information technology are speed, consistency, accuracy, and reliability. Research conducted by Bandi (2006) shows that corporate information technology investments affect the company's performance. Rahadi (2007) stated that information technology is very fundamental in improving services in the public sector. Sari dan Handayani (2015) argue that the increasing use of information technology available in government institution will also increase the accountability of government performance.

Organizations must not only consider rational factors namely availability of resources, orientation to goals and information that can enhance expertise, but also consider the influence of the political environment, such as organizational culture (Sadjiarto, 2008). The organization must pay full attention and make employees trust the organization so that that employee commitment will be obtained. If employee commitment is obtained, then loyal employees are obtained (Kurniawan, 2010). Concerning organizational commitment, Mayer and Allen (1997) identified three themes in defining commitment. The three themes are affective commitment, ongoing commitment, and normative commitment (Sutrisno, 2010).

Zodia (2015) reveals that organizational commitment influences the performance of the government institution. Wardhana and Astika (2015) found that organizational commitment influences government accountability performance and encourage individual performance. Organizational commitment has the potential to 
influence the relationship between competence and performance accountability, the higher the organizational commitment of the heads of regional government working units; the effort to improve performance accountability will also increase.

\section{Literature Review and Hypothesis Development}

\section{Accountability Performance of Government Institution}

Accountability is the responsibility or circumstances to be accounted for or the condition requested for accountability (Bastian, 2010:88). Whereas according to Tanjung (2014:11), accountability is the responsibility of managing the resources and carrying out the activities of a reporting entity entrusted to the reporting entity in achieving the objectives set periodically. Presidential Regulation Number 29 of 2014 concerning Performance Accountability Systems of Government Institution defines performance accountability as a manifestation of the obligation of a government agency to account for the success or failure of programs and activities that have been mandated by stakeholders in order to achieve the measurable organizational mission with performance targets or targets which has been determined through periodic government agency performance reports. Accountability is carried out by taking into account performance indicators, which are quantitative and qualitative measures that describe the level of achievement of a goal or goal that is more determined by considering indicators of input, output, process, outcome, benefit and impact.

\section{Government Internal Control System}

Government internal control system is an integral process of actions and activities carried out continuously by the leadership and all employees to provide adequate confidence in the achievement of organizational goals. It enables reliability of financial reporting, protection government assets from fraud, and compliance of legislation (Suwanda, 2019:110111). The implementation of the internal control system of government institution aims to provide adequate confidence for the achievement of effectiveness and efficiency of the objectives of the administration of state and regional governments, the reliability of financial reporting, protection of state assets, and compliance with statutory regulations (Government Regulation 60/2008). The elements of the government internal control system according to government regulation number 60/2008 in article 3 point 1 consist of the control environment, risk assessment, control activities, information and communication, and control monitoring.

\section{Information Technology Utilization}

Information technology combines computerization and communication for data, voice and video (Williams and Sawyer, (2007). Thompson et al. (1991) define the use of information technology as the choice of individuals to use information technology in carrying out their duties or behaviour of using technology in a working environment. The measurement is based on the intensity of utilization, frequency of utilization, and the number of applications or software used. The central government and local governments are obliged to develop and utilize information technology advancements to improve the ability to manage government financial information. According to Zanaria (2017), information technology aims to help organizations in carrying out daily operational activities. Implementation of information technology in organizations can increase government performance and potentially prevent fraud in the organization. According to Sutarman (2012), the benefits of the application of information technology are speed, consistency, accuracy, and reliability. Hamzah (2009) states that the government needs to optimize the use of information technology advancements to build a management information system network and work processes that enable the government to work in an integrated manner by simplifying access between work units. According to Darmini and Wijana (2007), measurement of information technology utilization is based on the following: intensity utilization, frequency utilization, and diversity of software package utilization.

\section{Organizational Commitment}

In organizational behaviour, there are various definitions of organizational commitment. 
Sutrisno (2010) states that organizational commitment is a strong desire to become members in a group and belief and acceptance of organizational values and goals. Meanwhile, according to Robbin and Judge (2008) argue that organizational commitment is a situation where an employee takes sides with the goals of the organization and has a desire to maintain membership in the organization. Organizational commitment is an employee behaviour related to trust and acceptance of the goals and values of the organization, the willingness to work towards achieving organizational interests, and the desire to maintain the position as a member of the organization. Robbins and Judge (2008) classify organizational commitment into three separate indicators, namely affective commitment, continuance commitment, normative commitment. According to Luthans (2010) that there are three aspects of commitment, namely affective commitment, continuance commitment, and normative commitment. Commitment is also associated with conformity between individuals and organizations. The cause of affective commitment is more related to experience in work that can satisfy individual needs so that they feel comfortable and competent in carrying out their role in work. Ongoing commitments and normative commitments are more related outside of direct work experience. Continuous commitment develops from various events that increase the price that must be borne if leaving the organization.

\section{Internal Control Systems and Government Accountability Performance}

The internal control system is activities carried out by management continuously to provide adequate confidence to achieve organization goals (Government Regulation 60/2008). Afrina (2015) found that internal control activities in government institutions improve the overall process of activities. Dharmawan and Supriatna (2016), Pujiono.et.al (2016) revealed that the internal control system had a positive effect on the performance of a government institution. Fitrawati, et al. (2017) argues that a sound internal control system in an organization will be able to create an excellent overall process of activities. It will provide a belief for the organization that the activities have been carried out following effectiveness and efficiency principle, and this will have a positive impact on the performance of the organization. Erawati (2019) revealed that internal control had a negative effect on organizational performance due to the lack of internal control within an organization. It implies that the existence of an internal control system empirically proven to improve the performance of local government. Therefore, the hypothesis is formulated as follows:

$\mathrm{H}_{1}$ : The better government internal control system, the higher government accountability performance will be

Information Technology Utilization and Government Accountability Performance

Research conducted by Zodia (2015) revealed that information technology utilization does not affect the performance of the government institution. It is due to the lack of competent human resources, lack of training and a limited budget for the development of information technology. Sari and Handayani (2015) found that implementation of information technology in the organization will have a significant impact not only on work efficiency but also on work culture both between individual and throughout the institution. Lestari (2015) revealed that information technology utilization has a positive impact on organizational performance in terms of length of time of operation processing and cost-efficiency. Chintya (2017) found that information technology utilization will have a positive influence on organizational performance if it is used optimally. Erawati dan Winangsit (2019) also proved that information technology utilization has a positive effect on organizational performance. Therefore, the hypothesis is formulated as follows

\section{$\mathrm{H}_{2}$ : The better information technology utilization, the higher government accountability performance will be}

\section{Organizational Commitment and Government Accountability Performance}

Organization commitment can be identified as an effort to achieve organizational goals with a willingness to direct all power to the interests of the organization (Sutrisno, 2017). Wardhana et al. (2015) revealed that organizational 
commitment strengthens the influence of human resources competence on accountability performance of government institution. Research conducted by Zodia (2015) and Febrian (2016) revealed that organizational commitment has a positive effect on the performance of the government institution. In contrast, Revika's research (2015) revealed that organizational commitment did not influence the performance of the government institution. Research conducted by Erawati and Winangsit (2019) also revealed that organizational commitment has a negative effect on organizational performance. Even though the findings of studies indicate mixed results, in this paper, the hypothesis is proposed as follows:

$\mathrm{H}_{3}$ : The higher organizational commitment, the higher government accountability performance will be

\section{Research Methods}

Type of research in this study is verification research with a quantitative-explanatory approach. The study aims to verify and explain the causal relationship between various variables through hypothesis testing (Sekaran and Bougie, 2017). Data collection this research is categorized as survey research. Survey research is a primary data collection method obtained directly from the source. The analytical method used in this study uses multiple regression analysis using the SPSS program. This study uses a single cross-section design. In this study data and information were collected from respondents through questionnaires.

Tabel 1. Variable Operationalization

\begin{tabular}{|c|c|c|}
\hline Variable & Dimensions & Indicators \\
\hline \multirow{5}{*}{$\begin{array}{l}\text { Internal Control } \\
\text { System (X1) }\end{array}$} & $\begin{array}{l}\text { 1. Control } \\
\text { Environment }\end{array}$ & $\begin{array}{l}\text { 1. Enforcement of integrity and ethical values. } \\
\text { 2. Commitment to competence. } \\
\text { 3. Establishment of organizational structure that suits } \\
\text { the needs. } \\
\text { 4. Delegation of appropriate authority and } \\
\text { responsibilities. }\end{array}$ \\
\hline & $\begin{array}{l}\text { 2. Risk } \\
\text { Assessment }\end{array}$ & $\begin{array}{l}\text { 1. Use good mechanisms to recognize risks from } \\
\text { external and internal factors. } \\
\text { 2. Assessing factors that can increase risk }\end{array}$ \\
\hline & $\begin{array}{l}\text { 3. Control } \\
\text { Activities }\end{array}$ & $\begin{array}{l}\text { 1. Performance Review. } \\
\text { 2. Physical control of assets. } \\
\text { 3. Determination and evaluation of Indicators. }\end{array}$ \\
\hline & $\begin{array}{l}\text { 4. Information and } \\
\text { Communication }\end{array}$ & $\begin{array}{l}\text { 1. Organizing effective communication and } \\
\text { information. } \\
\text { 2. Management and development of information } \\
\text { systems continuously. }\end{array}$ \\
\hline & 5. Monitoring & $\begin{array}{l}\text { 1. Monitoring the control system is carried out through } \\
\text { continuous monitoring } \\
\text { 2. Follow-up on the recommendations of the audit } \\
\text { results and reviewing others. }\end{array}$ \\
\hline \multirow[b]{3}{*}{$\begin{array}{l}\text { Information } \\
\text { Technology } \\
\text { Utilization (X2) }\end{array}$} & $\begin{array}{l}\text { 1. Intensity } \\
\text { Utilization }\end{array}$ & $\begin{array}{l}\text { 1. Intensity of computer utilization } \\
\text { 2. Intensity of internet utilization }\end{array}$ \\
\hline & $\begin{array}{l}\text { 2. Frequency } \\
\text { Utilization }\end{array}$ & $\begin{array}{l}\text { 1. Speed in working } \\
\text { 2. Speed in the work process }\end{array}$ \\
\hline & $\begin{array}{l}\text { 3. } \begin{array}{l}\text { Number of } \\
\text { devices } \\
\text { utilization }\end{array}\end{array}$ & $\begin{array}{l}\text { 1. Number of devices owned } \\
\text { 2. The capacity of the devices utilization }\end{array}$ \\
\hline
\end{tabular}




\begin{tabular}{|c|c|c|}
\hline Variable & Dimensions & Indicators \\
\hline \multirow{3}{*}{$\begin{array}{l}\text { Organizational } \\
\text { Commitment } \\
\text { (X3) }\end{array}$} & $\begin{array}{l}\text { 1. Affective } \\
\text { Commitment }\end{array}$ & $\begin{array}{l}\text { 1. Sense of Ownership } \\
\text { 2. Emotional feelings attached } \\
\text { 3. Personal meaning }\end{array}$ \\
\hline & $\begin{array}{l}\text { 2. Continuance } \\
\text { Commitment }\end{array}$ & $\begin{array}{ll}\text { 1. } & \text { Choices } \\
\text { 2. } & \text { Benefit }\end{array}$ \\
\hline & $\begin{array}{l}\text { 3. Normative } \\
\text { Commitment }\end{array}$ & 1. Confidence to be loyal \\
\hline \multirow{5}{*}{$\begin{array}{l}\text { Government } \\
\text { accountability } \\
\text { Performance (Y) }\end{array}$} & $\begin{array}{l}\text { 1. Legal and } \\
\text { Honesty } \\
\text { Accountability }\end{array}$ & $\begin{array}{l}\text { 1. Laws and regulations. } \\
\text { 2. Applying regulations in preparing regional budgets } \\
\text { and spending. }\end{array}$ \\
\hline & $\begin{array}{l}\text { 2. Process } \\
\text { Accountability }\end{array}$ & $\begin{array}{l}\text { 1. Compliance with reporting. } \\
\text { 2. Performance information utilization. } \\
\text { 3. The existence of service standards. }\end{array}$ \\
\hline & $\begin{array}{l}\text { 3. Programme } \\
\text { Accountability }\end{array}$ & $\begin{array}{l}\text { 1. Each program is carried out according to the } \\
\text { objectives. } \\
\text { 2. Consider programs that provide optimal results. }\end{array}$ \\
\hline & $\begin{array}{l}\text { 4. Policy } \\
\text { Accountability }\end{array}$ & $\begin{array}{l}\text { 1. Reported performance } \\
\text { 2. Leadership involvement }\end{array}$ \\
\hline & $\begin{array}{l}\text { 5. Financial } \\
\text { Accountability }\end{array}$ & $\begin{array}{l}\text { 1. Budget and expenditure implementation. } \\
\text { 2. Financial statements are presented with reference to } \\
\text { the applicable Government Accounting Standard. } \\
\text { 3. The financial statements presented provide relevant } \\
\text { financial information. }\end{array}$ \\
\hline
\end{tabular}

This study uses purposive sampling technique, and it refers to a deliberate sampling technique following the required sample criteria. The criteria used as research samples are 1) districts/municipals in West Java that have CC (adequate) and $\mathrm{C}$ (insufficient) government accountability performance 2) districts/municipals in West Java that have the unrealized burden below $90 \%$ of the budget. After applying the procedure of purposive sampling, the selected samples are Majalengka District, Purwakarta District, Karawang District, Tasikmalaya District, Sumedang Regency, and Pangandaran District. The respondents are the head of the government office, the government office secretary, the planning and financial section of government units

\section{Result and Discussion}

\section{Descriptive Analysis}

The summary of government internal control system is presented in table 1. Based on information in table 1 , the respondent's assessment of the internal control system was obtained an average score of $64.71 \%$. The control environment dimension gets the highest average score of $67.73 \%$, and the control activities dimension gets the lowest average score. The percentage gap is $35.29 \%$ for this variable, and it indicates that government internal control system must be continuously improved to achieve ideal conditions.

Table 1. Frequency Distribution of Government Internal Control Systems Variable

\begin{tabular}{|c|l|c|c|c|c|}
\hline \multirow{2}{*}{ No } & \multirow{2}{*}{ Dimension } & \multicolumn{2}{c|}{ Score } & \multirow{2}{*}{$\begin{array}{c}\text { Score } \\
\%\end{array}$} & $\begin{array}{c}\text { Gap } \\
\%\end{array}$ \\
\cline { 3 - 4 } & & Actual & Ideal & & 32.27 \\
\hline 1 & Control environment & 508 & 750 & 67.73 & 32.67 \\
\hline 2 & Risk assessment & 191 & 300 & 63.67 & 36.33 \\
\hline 3 & Control activities & 280 & 450 & 62.22 & 37.78 \\
\hline
\end{tabular}




\begin{tabular}{|c|l|c|c|c|c|}
4 & Information and communication & 187 & 300 & 62.33 & 37.67 \\
\hline 5 & Monitoring and evaluation & 193 & 300 & 64.33 & 35.67 \\
\hline \multicolumn{2}{|c|}{ Total } & 1359 & 2100 & 64.71 & 35.29 \\
\hline
\end{tabular}

Based on information in Table 2, the respondents' assessment of the information technology utilization gets an average score of $64.71 \%$. The intensity utilization dimension gets the highest average score of $66 \%$, and frequency utilization dimension gets the lowest average score of $62.33 \%$. The percentage gap of $36.00 \%$ for this variable, it indicates that the sample of study must continue to improve information technology utilization to achieve ideal conditions.

Table 2. Frequency Distribution of Information Technology Utilization Variable

\begin{tabular}{|c|l|c|c|c|c|}
\hline \multirow{2}{*}{ No } & \multirow{2}{*}{ Dimension } & \multicolumn{2}{|c|}{ Score } & \multirow{2}{*}{$\begin{array}{c}\text { Score } \\
\%\end{array}$} & $\begin{array}{c}\text { Gap } \\
\%\end{array}$ \\
\cline { 3 - 4 } & & Actual & Ideal & $\%$ & 34.00 \\
\hline 1 & Intensity Utilization & 198 & 300 & 66.00 & 37.67 \\
\hline 2 & Frequency Utilization & 187 & 300 & 62.33 & 37.67 \\
\hline 3 & Number of Applications Utilization & 191 & 300 & 63.67 & 36.33 \\
\hline \multicolumn{2}{|c|}{ Total } & 576 & 900 & 64.00 & 36.00 \\
\hline
\end{tabular}

Based on information in Table 3, the respondents' assessment of the organizational commitment obtains an average score of $70.22 \%$. The dimensions of affective commitment get the highest average score of
$73.78 \%$. The gap percentage is $29.78 \%$ for this variable, and it indicates that the sample of study must continue to increase organizational commitment to achieve ideal conditions.

Table 3. Frequency Distribution of Organizational Commitment Variable

\begin{tabular}{|c|l|c|c|c|c|}
\hline \multirow{2}{*}{ No } & \multirow{2}{*}{ Dimension } & \multicolumn{2}{|c|}{ Score } & \multirow{2}{*}{$\%$} & \multirow{2}{*}{ Criteria } \\
\cline { 3 - 4 } & & Actual & Ideal & & \\
\hline 1 & Affective Commitment & 332 & 450 & 73.78 & 26.22 \\
\hline 2 & Continuance Commitment & 200 & 300 & 66.67 & 33.33 \\
\hline 3 & Normative Commitment & 100 & 150 & 66.67 & 33.33 \\
\hline \multicolumn{2}{|c|}{ Total } & 632 & 900 & 70.22 & 29.78 \\
\hline
\end{tabular}

Based on information in Table 3, respondents' assessment of the government accountability performance obtained an average score of $68.06 \%$. The dimensions of the accountability program get the highest average score of $75.67 \%$ and the financial accountability dimension get the lowest average score of $59.67 \%$. When viewed from the gap percentage of $31.94 \%$ for this variable, it indicates that the unit of analysis must continue to improve government institution performance accountability to achieve ideal conditions. 
Tabel 4. Frequency Distribution of Government Institution Performance Accountability Variable

\begin{tabular}{|c|l|c|c|c|c|}
\hline \multirow{2}{*}{ No } & \multirow{2}{*}{ Dimension } & \multicolumn{2}{c|}{ Score } & Score & Gap \\
\cline { 3 - 4 } & & Actual & Ideal & $\%$ & $\%$ \\
\hline 1 & Legal and honesty accountability & 204 & 300 & 68.00 & 32.00 \\
\hline 2 & Process accountability & 308 & 450 & 68.44 & 31.56 \\
\hline 3 & Program accountability & 227 & 300 & 75.67 & 24.33 \\
\hline 4 & Policy accountability & 205 & 300 & 68.33 & 31.67 \\
\hline 5 & Financial accountability & 179 & 300 & 59.67 & 40.33 \\
\hline \multicolumn{2}{|c|}{ Total } & 1123 & 1650 & 68.06 & 31.94 \\
\hline
\end{tabular}

\section{Regression Analysis}

Regression is a statistical analysis used in this study to predict the influence of government internal control system, information technology utilization, and organizational commitment to government accountability performance. The results indicate that all independent variables (government internal control system, information technology utilization, and organizational commitment) were found a significant influence on government accountability performance $(\mathrm{p}<0.05)$

Tabel 5. Regresion Output

\begin{tabular}{|ll|r|r|r|r|r|}
\hline \multirow{2}{*}{ Model } & \multirow{2}{*}{ Variable } & \multicolumn{2}{|c|}{$\begin{array}{c}\text { Unstandardized } \\
\text { Coefficients }\end{array}$} & $\begin{array}{c}\text { Standardized } \\
\text { Coefficients }\end{array}$ & \multirow{2}{*}{$\mathrm{t}$} & \multirow{2}{*}{ Sig. } \\
\cline { 3 - 6 } & \multicolumn{1}{c|}{$\mathrm{B}$} & \multicolumn{1}{c|}{ Std. Error } & \multicolumn{1}{c|}{ Beta } & & \\
\hline 1 & (Constant) & 10.172 & 3.569 & & 2.850 & .008 \\
& Internal Control System & .167 & .061 & .364 & 2.734 & .011 \\
& Information Technology Utilization & .290 & .129 & .288 & 2.238 & .034 \\
& Organizational Commitment & .684 & .208 & .384 & 3.284 & .003 \\
\hline
\end{tabular}

Model analysis is used to determine the degree or strength of the relationship between government internal control systems, the utilization of information technology and organizational commitment to government accountability performance simultaneously. Based on the information in Table 6 , the multiple correlation value $(\mathrm{R})$ is 0.874 . It means that the government internal control system, utilization of information technology, and organizational commitment to the government accountability performance has a substantial level of relationship.

Table 6. Model Summary

\begin{tabular}{|c|c|c|c|c|c|c|c|c|c|c|}
\hline \multirow[b]{2}{*}{ Model } & \multirow[b]{2}{*}{$\mathrm{R}$} & \multirow[b]{2}{*}{$\begin{array}{c}\mathrm{R} \\
\text { Square }\end{array}$} & \multirow[b]{2}{*}{$\begin{array}{l}\text { Adjusted } \\
\text { R Square }\end{array}$} & \multirow[b]{2}{*}{$\begin{array}{l}\text { Std. Error } \\
\text { of the } \\
\text { Estimate }\end{array}$} & \multicolumn{5}{|c|}{ Change Statistics } & \multirow[b]{2}{*}{$\begin{array}{l}\text { Durbin- } \\
\text { Watson }\end{array}$} \\
\hline & & & & & $\begin{array}{l}\text { R Square } \\
\text { Change }\end{array}$ & $\begin{array}{c}\mathrm{F} \\
\text { Change }\end{array}$ & df1 & $\mathrm{df} 2$ & $\begin{array}{c}\text { Sig. } \\
\text { F } \\
\text { Change }\end{array}$ & \\
\hline 1 & $.874^{\mathrm{a}}$ & .763 & .736 & 3.33769 & .763 & 27.938 & 3 & 26 & .000 & 1.638 \\
\hline
\end{tabular}




\section{Correlation Analysis}

Based on information in table 7, the correlation coefficient between the government internal control system and the government accountability performance is 0.762 (strong relationship). The correlation coefficient between the use of information technology to government accountability performance is 0.716 (strong relationship). The correlation coefficient between organizational commitment and government accountability performance is 0.727 (strong relationship).

Table 7. Correlation Analysis Output

\begin{tabular}{|ll|r|r|r|r|}
\hline & & \multicolumn{1}{c|}{$\mathrm{Y}$} & \multicolumn{1}{c|}{$\mathrm{X}_{1}$} & \multicolumn{1}{c|}{$\mathrm{X}_{2}$} & \multicolumn{1}{c|}{$\mathrm{X}_{3}$} \\
\hline Pearson & Performance Accountability & 1.000 & .762 & .716 & .727 \\
Correlation & Internal Control System & .762 & 1.000 & .649 & .547 \\
& Information Technology & .716 & .649 & 1.000 & .498 \\
& Utilization & .727 & .547 & .498 & 1.000 \\
\hline & Organizational Commitment & .000 & .000 & .000 \\
\hline Sig. (1-tailed) & Performance Accountability & .000 &. & .000 & .001 \\
& Internal Control System & .000 & .000 & & .003 \\
& Information Technology & .000 & .001 & .003 & \\
& Utilization & 30 & 30 & 30 & 30 \\
& Organizational Commitment & 30 & 30 & 30 & 30 \\
& Performance Accountability & 30 & 30 & 30 & 30 \\
& Internal Control System & 30 & 30 & 30 & 30 \\
\hline
\end{tabular}

\section{Discussion}

Results of the study indicated that the government internal control system significantly influences the government accountability performance in a positive direction. The government internal control system influences the government accountability performance in 6 districts in west java province by $27.76 \%$, and the rest is influenced by other factors such as the quality of financial statements, organizational culture, and others. The finding is consistent with previous researches by Dharmawan and Supriatna (2016), Pujiono et al. (2016), Fitrawati et al. (2017), Kaltsum and Rohman (2013), and Afrina (2015). Halim (2004) argues that to support accountability requires an excellent internal and external control system and public accountability can only be realized by the existence of an adequate supervision system from the government and demands the existence of an independent and objective professional audit institution. The government's internal control system in 5 districts/cities in the west java province have been implemented well but in specific dimensions are still not implemented optimally such as the control system in the implementation income and expenditure budget. The government internal control system must be socialized to all levels of employees and more importantly, how to implement it.

The implementation of information technology in organizations makes performance increase and narrows the gap for fraud in the organization. Result of the study indicates that the utilization of information technology has a significant effect on government accountability performance in a positive direction. Utilization of information technology has an effect of $20.62 \%$ on the accountability of government institution performance in 6 districts/cities in west java 
province and the rest is influenced by other factors such as the quality of financial statements, organizational culture, and others. The finding is in accordance with previous researches by Chintya (2017), Bandi (2006), and Rahadi (2007). The Electronic-Based Government System (SPBE) in regencies and cities in the province of West Java still has room for improvement. Accountants in each local government unit can maximize the use of information technology to improve services to the public and government accountability performance

Result of the study indicates that organizational commitment has a significant effect on government accountability performance in a positive direction. It means that the higher the organizational commitment, government accountability performance will also increase. Organizational commitment has an influence of $27.94 \%$ on government accountability performance in 6 districts/cities of West Java Province, and the rest is influenced by other factors such as the quality of financial statements, organizational culture, and others. The finding is consistent with the researches by Zodia (2015), Wardhana et al. (2015), Febrian (2016), and Astuti (2011). Organizational commitment can be identified from the work ethic and employee loyalty in carrying out all activities. Organizational commitment exists if individuals in the organization are aware of their rights and obligations in the organization without looking at the position and role. The achievement of organizational goals is the responsibility of all members of the organization collectively.

\section{Conclusion and Recommendation}

This study aims to examine the effect of the government internal control system, the use of information technology and organizational commitment on the government accountability performance in local government in West Java province. The results of the study indicate that all variable independent ( government internal control system, the use of information technology and organizational commitment) have a positive and significant effect on government accountability performance. In order to improve government accountability performance requires, local government should consider a sound internal control system, optimal utilization of information technology, and strong organizational commitment. For the next research, it is recommended to add some other independent variables that potentially influence government accountability performance and expand the research area in other local governments in Indonesia.

\section{References}

Afrina, Dina. 2015. The Effect of Application of Local Government Accounting Systems, Internal Controls and Reporting Systems on the Performance of Government Agencies. Online Journal of FEKON Students. Vol 2 No.2.

Bandi. 2006. The Influence of Company Response in Information Technology Investment on Company Performance: Business Strategy, Information Technology Maturity, and Company Size as Antasedent Variables. SNA IX (accessed: https://id.scribd.com/doc/ 13065865/influence-response-companyin-investment-information-technology-toperformance-company-strategy-businessmaturity-information-technology-andsize).

Bastian, Indra. 2010. Public Sector Accounting: An Introduction. Third Edition. Erlangga Publisher: Jakarta.

Chintya, Irine. 2015. The Influence of Information Technology Utilization and Government Internal Control Systems on the Performance of Government Agencies in Solok City (Study on Solok City Government SKPD). Thesis of Padang State University.

Darmini Rai, Anak Agung Sagung and I Nyoman Wijana Asmara Putra. 2007. Utilization of Information Technology and Its Effect on Individual Performance in People's Credit Banks in Tabanan Regency. Journal of Udayana University.

Destriyani, Vini, et al. 2015. The Effect of Good Governance, Quality of Human Resources, Utilization of Information Technology and Internal Control on Organizational Performance (Study on the Work Unit of the 
Meranti Islands Regency). Online Journal of Students of the Faculty of Economics, University of Riau, vol. 2, no. 2, Oct. 2015.

Dharmawan, Muhammad Taufan and Nono Supriatna. 2016. The Influence of the Implementation of the Internal Control System on the Performance of Government Agencies (Case Study in the Organization of the Government of Bandung City). Journal of Accounting and Financial Research Vol 04 No 01, e-ISSN: 2541061X p-ISSN: 2338-1507.

Erawati, Teguh, and Winangsit, Wiku. 2019. The Effect of Utilization of Information Technology, Internal Control and Organizational Commitment on Organizational Performance (Empirical Study of the Work Unit of Gunungkidul Regency). Dewantara Tax Accounting Journal Volume 1 Number 1.

Febrian. 2016. The Effect of Good Governance, Compensation, Organizational Commitment, Motivation and the Work Environment on the Accountability of Government Institution Performance (Case Studies on all SKPD Bintan District Government). Raja Ali-Haji Maritime University Repository.

Fitrawati, Kahar Abdul, and Muh.Ikbal A. 2017. Effect of Clarity of Budget Targets and Internal Control Systems on the Accountability of the Performance of Government Agencies (Survey on the Regional Work Unit (SKPD) of Parigi Mountong Regency. E Journalist Catalog, Vol. 5 No. 12 ISSN: 2302-2019.

Government Regulation Number 60 Year 2008 concerning Internal Control Systems of Government Institution.

Halim, Abdul. 2002. Public Sector Accounting Regional Financial Accounting. First edition. Jakarta: Salemba Empat.

Hamzah, Ardi. 2009. "Evaluation of the Conformity of the Behavioral Model in the Use of Information System Technology in Indonesia, National Seminar on Information System Application and Information Technology (SNSTI)". Yogyakarta, June 20, 2009.

Indrayani, Ni Made Manik, and Sudibya, Gede Adnyana. 2017. Effect of Organizational
Commitment and Job Stress on Turnover Intention. Udayana Management EJournal, Vol. 6, No. 11, 2017: 6241-6270. ISSN: 2302-8912.

Jurnali, Teddy and Bambang Supomo. 2002. "The Effect of Factor Conformity in Technology Task and Utilization of Information Technology on Public Accountant Performance". Indonesian Accounting Research Journal ISSN 14106817 Vol.5.No.2, Pages: 214-228.

Kaltsum, U., \& Rohman, A. (2014). The Effect of Clarity of Budget Targets on the Accountability of Government Agencies' Performance Through Internal Control Systems as an Intervening Variable (Empirical Study of the Salatiga Municipal Work Unit). Diponegoro Journal of Accounting, 3 (1), 215-228.

Karmila; Tanjung, Amries Rusli and Edfan Darlis. Influence of Human Resources Capacity Utilization of Information Technology and Internal Control Against the Reliability of Local Government Financial Reporting (Study on the Government of Riau Province). Highlight Journal Vol 9 No. 1 pp. 1-121 ISSN: 1907364X.

Kurniawan, Albert. 2014. Research Methods for Economics and Business: Theory, Concepts and Practices of Business Research (Equipped with Data Processing Calculations with IBM SPSS 2.0). Bandung: Alfabeta.

Kurniawan, Muhammad Rizki Nur and Andri Prastiwi. 2010. Effect of Organizational Commitment, Organizational Culture, and Job Satisfaction on Public Organizational Performance. Research Lecturer, Diponegoro University: Semarang.

Lestari, T. P. 2015. "The Influence of Information Technology, Internal Control and Leadership Style on the Performance of Government Agencies" (Empirical Study on Bengkalis Regency SKPD). General Fecon. Vol. 2 No.2 October.

Luthans, Fred. 2010. Organizational Behavior An Evidence-Based Approach. Twelfth Edition. University of Nebraska ISBN-13: 978-0-07-353035-2. 
Mardijono, Didik Eko. 2009. Analysis of the Effects of Leadership, Utilization of Information Technology and the Implementation of Decentralized Organizational Structure on Organizational Performance. Diponegoro University Thesis.

Meyer, John P., and Allen, Natalie J. 1991. A Three-Component Conceptualization of Organizational Commitment. Human Resource Management Review, 1 (1): 61 89.

Sekaran, Uma and Bougie, Roger. 2017. Research Methods for Business. Issue 6, book 1. South Jakarta: Salemba Empat.

Pamungkas, Bambang. 2012. Effect Of Public Sector Accounting Application And Supervision of The Quality Of Financial Statements and their Implications for The Accountability of The Performance ff Government Agencies. Ranggading Scientific Journal 12 Vol 2 pp 82-93.

Pratiwi, Ririh Dian and Setyowati, Lilis. 2017. Determinants That Affect Performance Accountability of Semarang City Government. Journal of Business and Economics (JBE) ISSN: 1412-3126.

Presidential Regulation Number 29 Year 2014 concerning Performance Accountability Systems of Government Agencies.

Pujiono, Dodik Slamet; Sukarno, Hari; and Novi Puspitasari. 2016. Effect of Internal Control Systems on Regional Financial Management and Local Government Performance (North Maluku Province Study). Journal of Business and Management Vol 10 No. 1 pp. 68-81.

Rahadi, Dr. Dedi Rianto. 2007. The Role of Information Technology in Improving Services in the Public Sector. 2007 National Seminar on Technology (SNT2007) ISSN: 1978-9777.

Ramdhan 2014. Implications of Government Agencies Performance Accountability Reports in the Context of Realizing Regional Financial Management Policies Based on Good Governance. Journal of Brawijaya University Faculty of Law Malang.
Revika, R. 2015. The Influence of the Quality of Human Resources, Organizational Commitment, and Budget Participation on the Performance of Payakumbuh Regional Work Units (SKPD). Journal of the Faculty of Economics, Riau University, Pekanbaru. Vol. 20 No.1Robbins, Stephen P. and Judge, Timothy A. (2008). Organizational Behavior 12th Edition, Jakarta: Salemba Empat.

Sadjiarto, Arja. 2008. Accountability and Measurement of Government Performance. Journal of Accounting \& Finance Volume 2 Number 2.

Santoso, Susan. 2013. Analysis of Performance Accountability Reports at the North Sulawesi Provention Culture and Tourism Office. Faculty of Economics and Business, Accounting Department, Sam Ratulangi University, Manado. ISSN 2303-1174.

Sari, Kartika Eka and Handayani, Nur. 2015. The Influence of Information Technology Utilization and Internal Control on Performance Accountability. Journal of Accounting Science \& Research Vol.4 No.9 (2015).

Silaban, Jelita Nur Evelyn. 2017. The Influence of Internal Control, The Use of Information Technology, and Human Resource Competencies on The Quality of Financial Reports In The Regency Government Is Different With Organizational Commitment as A Moderating Variable. University of North Sumatra Repository Thesis http://repositori.usu.ac.id/handle/1234567 $89 / 641$

Supreme Audit Agency. 2018a. Summary of Semester I Examination Results for 2017. Book II Examination of Financial Statements.

Sutarman 2012. Introduction to Information Technology. Jakarta: PT. Bumi Aksara.

Sutrisno, Edy. 2010. Organizational Culture. Prenada Media Grup: Jakarta.

Suwanda, Dadang, et al. 2019. Risk Management in Regional Financial Management as an Effort to increase Transparency and Public Accountability. Bandung: PT Youth Rosdakarya Offset. 
Tanjung, Abdul Hafiz. 2014. Accounting, Transparency, and Public Financial Accountability. Yogyakarta: UGM BPFE.

Thompson, Ronald L: Higgins Chriatoper A .; and Howell, Jane M .; "Personal Computing Toward a Conceptual Model of Utilization”, MIS Quarterly, March 1991, 125-143.

Tiasari, Hannum. 2013. The Relationship Between Internal Control and Accountability of the Performance of Government Agencies Revenue Service Offices in East Java Province. Journal of Policy and Public Management Vol 1 No. 2 ISSN 2303-34IX.

Wardhana, Rasmini and Astika. 2015. Effect Of Competence On Performance Accountability of Government Agencies With Organizational Commitment as A Moderating Variable. E-journal of Economics and Business, Udayana University, ISSN: 2337-3067.
Williams, B. K., \& Sawyer, S. C. (2007). Using Information Technology: A Practical Introduction to the World of Computers and Communications (Issue 7) (Translator: Nur Wijayaning Rahayu \& Th. Arie Prabawati). Yogyakarta: ANDI.

Yani, Ahmad. 2002. Financial Relations Between Central and Local Governments in Indonesia. Jakarta: PT. Raja Grafindo Persada.

Zanaria, Yulitas. 2017. Effect of Application of Technology, Accounting Reporting on Fraud Prevention and Its Implications on Investor Reactions. Acquisition: Accounting Journal Volume 13 Issue 1.

Zodia, Adif Putra. 2015. The Effect of Utilization of Information Technology, Internal Control Systems and Organizational Commitment on the Performance of Government Agencies. Student Online Journal Volume 2, Number 2 